\title{
Instagram: Balancing Information Asymmetry of the Tourism Industry
}

\author{
Josué Gutiérrez-Barroso*(iD, Alberto Javier Báez-García**iD, \\ Francisco Flores-Muñoz ${ }^{* * *}$, Diego Valentinetti ${ }^{\$}$ id
}

\begin{abstract}
This study focuses on the use of Instagram by tourism companies. Specifically, it aims to analyze how Instagram empowers individuals over corporations in the digital dialogue, thus balancing the information asymmetry between corporations and stakeholders. Four categories of metrics have been collected to analyze the use of Instagram by companies: presence, impact, conversation, and influence. Additionally, OLS regressions have been performed to identify potential explanatory factors to explain the different behavior of each firm and its corresponding communities. While the use of Instagram by the selected firms is still scarce, significant results are as follows: corporations are using Instagram as an additional channel in their current communication; some explanatory factors account for significant differences in countries, size, and industries; and users are somehow reactive to the stream of pictures and texts disclosed by firms. The presence and impact of companies on Instagram are a highly important source for driving stakeholders' conversation within the digital arena.
\end{abstract}

Keywords: social network sites; information asymmetry; tourism; Instagram; corporate disclosure.

JEL classification: Z1; L8; M1

\section{INTRODUCTION}

The influence of communications channels in the mitigation of information asymmetries between corporations and its stakeholders has received much attention by researchers. The specific role of information intermediaries has been also explored, considering, among others, experts like auditors and financial analysts (Healy \& Palepu, 2001). As the digital environment

\footnotetext{
Faculty of Education, Universidad de La Laguna, San Cristóbal de La Laguna, Santa Cruz de Tenerife, Spain; e-mail:jgutierb@ull.edu.es.

Faculty of Economics, Business and Tourism, Universidad La Laguna, San Cristóbal de La Laguna, Santa Cruz de Tenerife, Spain; e-mail: abaegarc@ull.edu.es.

Iriarte University College, Universidad de La Laguna, Puerto de la Cruz, Santa Cruz de Tenerife, Spain; e-mail: ffloremu@ull.edu.es.

Department of Economic studies, University "G. d'Annunzio" of Chieti-Pescara, Italy; e-mail: d.valentinetti@unich.it (corresponding author).
} 
evolved, particularly with the rise of social media platforms, these intermediaries include now also non-experts, individuals that are able to filter information from the reporting firms and to generate opinion among stakeholders: influencers, as defined by Freberg, Graham, McGaughey, and Freberg (2011). It is not clear how these new intermediaries are interacting with the reporting firms and how they could be able to affect corporate transparency and, therefore, information asymmetry. Interestingly, recent digital tools like Google Trend are being recognized as effective online popularity performance metrics within the corporate disclosure practices - see e.g., Mora Rodríguez, Flores Muñoz, and Valentinetti (2021). Corporate digital communication between customers and companies, since the advent of Web 2.0, has been bidirectional (Grancay, 2014; Howard, Mangold, \& Johnston, 2014). Social networks could empower firms to maintain frequent contact with their diverse stakeholders, influencing sales and investors' affective reactions to corporate news (Marine-Roig, Martin-Fuentes, and DariesRamon (2017); Farkas and Keshk (2019)). Nevertheless, "users go on social media to connect with people, whereas marketers intend to sell things" (Zhu \& Chen, 2015, p. 335), and this type of erroneous position could reduce effectiveness (Grancay, 2014). This is why corporate behavior in this context is also evolving to a more comprehensive corporate dialogue, combining presence with conversation (Bonson Ponte, Torres, Royo, \& Flores Muñoz, 2012).

Instagram is considered the fastest growing social network with high potential for brand awareness and management purposes Eagleman (Geurin-Eagleman \& Burch, 2016). It is devoted to picture and video sharing, and it is currently integrated into other social networks such as Facebook or Twitter. In fact, Facebook acquired Instagram in 2012. Photographs can be directly shared from the smartphone, enabling amateur photographers to resemble the work done by professionals (Thelander \& Cassinger, 2017). It is also possible to publish small videos or stories, along with the corresponding texts and hashtags "\#", similar to Twitter (Schmidbauer, Rosch, \& Stieler, 2018). Therefore, the rapid rise of Instagram led research to uncover and understand the social and psychological factors behind the users' motives for using the new platform (E. Lee, Lee, Moon, \& Sung, 2015; MacDowall \& de Souza, 2018).

Instagram is specifically being used extensively in the area of tourism (Fatanti \& Suyadnya, 2015), specifically by the more influential instagrammer who uses the social network as a tool of personal promotion showing parts of his private life. Instagrammers are enabled to show images that seek an authenticity far from social conventions (Liu \& Suh, 2017) and it is also possible to follow a specific account without the need for reciprocity. As part of the instagrammer experience, in this social network it is possible to create a thread of photographs with a specific theme, like a destination or a specific corporation. It is about creating new tourism experiences (Harrigan, Evers, Miles, \& Daly, 2017) in which instagrammers have a lot to say sharing "their travel experiences so that they help other travelers in their decision-making process" (Gretzel, Sigala, Xiang, \& Koo, 2015, p. 181).

In summary, Instagram, due to its particular features, seems to empower individuals over corporations in the digital dialogue and it is still a pending task to assess the extent to which global corporations, in particular in the dynamic environment of the tourist industry, and their main instagrammers, are mutually evolving to overcome information asymmetries. This work contributes to this research challenge with incremental empirical evidence and the corresponding preliminary analysis, along with a proposal for relevant variable constructs based on key metrics. The next section provides a review of the studies on the use of Instagram in the context of corporate dialogue. Sections 3 and 4 explain the methodology and results of this research, respectively. Implications and conclusions are outlined in the last section. 


\section{PREVIOUS STUDIES}

A growing number of scholars addressed the role of social media in business research in different contexts, including corporate disclosure, markets' reaction and firms' valuation assessment - see e.g., L. F. Lee, Hutton, and Shu (2015); Boylan and Boylan (2017); Debreceny, Wang, and Zhou (2019); Farkas and Keshk (2019); Kipp, Zhang, and Tadesse (2019). In this context, empirical studies document how Instagram represents a powerful and fast tool to establish and maintain a long-term corporate dialogue with stakeholders (see Annex 1). An interesting topic is the intellectual capital disclosure. In this regard, Lardo, Dumay, Trequattrini, and Russo (2017) find that popularity metrics in social media are determinants of the value of human and relational capital in football industry. Their analysis shows how social media can be a relevant and timely tool for disclosing intellectual capital information. Another example is provided by Ramirez and Tejada (2019), who find that great importance to online disclosure of specific information about intellectual capital is devoted by university stakeholders. Specifically, structural and relational capital information is mainly disclosed in social media, including Instagram. Therefore, social media are recognized among the alternative tools for enhancing corporate disclosure transparency and stakeholder engagement in a timely and innovative fashion.

Another interesting issue is the role of Instagram in corporate communication compared to other social media. For example, Romao, Moro, Rita, and Ramos (2019, p. 21) find that while "Facebook still remains the dominant social network for any brand that wants to exhibit and generate buzz around its products and the brand itself [...] Instagram is more targeted for niche and luxury brands due to its visual characteristics". Similarly, Caputo, Buhnova, Evangelista, and Russo (2017) find that Instagram is more effective than Facebook in relation to three relationships: the frequency, the instability, and the previous activities in companies' communication on social media. On the other hand, the use of Insta-stories that last for only 24 hours leads to "the need to be constantly and consistently creating content for the viewers to look at. It also means that brands who want to stay relevant (and retain and add followers) need to keep up." (Clair \& Mandler, 2019, p. 53).

Research on the use of Instagram is also pursued taking into account psychological and behavioral aspects behind the purchasing intention - see e.g., Amornpashara, Rompho, and Phadoongsitthi (2015); Hosseini and Ghalamkari (2018); Waheed, Farrukh, Zameer, and Khan (2019). Interesting evidence is provided by Sembada and Koay (2019, p. 6), i.e., "the presence of perceived control over alternate channels of purchase as a significant influencer for the trust placed on social media shops". Specifically, they find that when consumers perceive they are in control of how they could obtain desired goods, trust becomes a function of the perceived safety and ease of use of the shops. On the other hand, Casalo, Flavian, and Ibanez-Sanchez (2020, p. 7) find that "perceived originality and uniqueness of the posts on an Instagram account are the key factors that lead a poster to be perceived as an opinion leader". Therefore, their main implication for research is that an ongoing relationship between companies and influencers is needed to mitigate the information asymmetry in corporate communication. 


\section{METHODS AND DATA}

\subsection{Sample and data collection}

The empirical study was conducted in October 2018, regarding the dataset comprised by the 111 global tourist corporations listed by STOXX 3000 Travel and Leisure (STOXX, 2018). Table no. 1 shows the breakdown of the sample by countries and subsectors.

Table no. 1 - Sample composition by countries and subsectors

\begin{tabular}{lr}
\hline Countries & 6 \\
\hline Australia & 3 \\
\hline Canada & 1 \\
\hline Chile & 4 \\
\hline France & 1 \\
\hline Germany & 15 \\
\hline Great Britain & 1 \\
\hline Greece & 4 \\
\hline Hong Kong & 2 \\
\hline Ireland & 21 \\
\hline Japan & 1 \\
\hline Korea & 2 \\
\hline Malaysia & 1 \\
\hline Philippines & 1 \\
\hline Sweden & 3 \\
\hline Singapore & 1 \\
\hline Thailand & 44 \\
\hline USA & $\mathbf{1 1 1}$ \\
\hline Total
\end{tabular}

\begin{tabular}{lr}
\hline Subsectors & \\
\hline Accommodation & 10 \\
\hline Intermediation & 5 \\
\hline Other leisure & 57 \\
\hline Transport & 39 \\
\hline
\end{tabular}

As a first step of this exploratory study, we have collected the primary metrics provided by the Instagram platform, organizing them in four categories in what implies an easily replicable model for contrast and forthcoming longitudinal studies:

(1) presence, to capture if the firms maintain an official profile and how active are;

(2) impact, to detect the feedback generated by these official profiles;

(3) conversation, to determine the level of interaction about the corporation in Instagram in which the firm is not controlling the discussion (hashtags, influencers), and

(4) influence, to measure the impact of that unofficial stream by means of the influencers.

Such categories were drawn from the literature on social media disclosure. Specifically, the first two categories of presence and impact link to Caputo et al. (2017, p. 27) concept of frequency, representing "evidence for companies' attention to communication based on the use of social networks". Such dimension can be framed in the signalling theory, for which companies rely on 'signals' to provide transparent information towards different stakeholders (Spence, 1973). Accordingly, we define several variables to measure the presence and impact categories, as shown in Table no. 2. Presence is mainly measured by the number of publications, along with the existence of videos and stories. These elements represent the external "signals" proving the digital presence and activity of each company in Instagram. We also consider the existence of links to the official corporate websites and network profiles 
(Facebook and Twitter). On the other hand, impact is measured combining several proxies used in previous research: the number of followers (Lardo et al., 2017), the number of likes (Romao et al., 2019) and the number of comments (Hosseini \& Ghalamkari, 2018). All these variables aim to take into account the users" "responses" in terms of feedback generated by the corporate official profiles.

The remaining categories conversation and influence are grounded on the concept of online interaction propensity, i.e., "the extent to which individuals like to get involved in online discussions" (Casalo et al., 2020, p. 4). Several studies recognize the importance of such aspect in the corporate communication processes - see e.g., Schlosser (2005); Blazevic, Wiertz, Cotte, de Ruyter, and Keeling (2014). For the purpose of our study, we consider two main crucial factors to measure the interaction between companies and stakeholders: hashtags and influencer, as shown in Table no. 3. Research is currently exploring the role of hashtags for enhancing the level of social media engagement, including the effectiveness of the existing analytics method for analyzing Instagram hashtag data - see e.g., Rosli and Husin (2019). Influencers are crucial as well, as current research recognize their role of opinion leaders in digital platforms. In summary, these variables are considered as digital proxies within the research on information asymmetry between companies and stakeholders.

Table no. 2 - Variables related to "presence" and "impact"

\begin{tabular}{lll}
\hline y_1 & Instagram profile & Dichotomous \\
\hline y_2 & Number of publications & Publications in the last month \\
\hline y_3 & Videos & Existence of videos (dichotomous) \\
\hline y_4 & Stories & Existence of stories (dichotomous) \\
\hline y_5 & $\begin{array}{l}\text { Link to corporate } \\
\text { website }\end{array}$ & $\begin{array}{l}\text { Existence of links to the official corporate website } \\
\text { (dichotomous) }\end{array}$ \\
\hline y_6 & Link to Facebook & Links to official social network profiles (dichotomous) \\
\hline y_7 & Link to Twitter & Number of followers \\
\hline y_8 & Followers & Average number of likes from publications collected for y_2 \\
\hline y_9 & Likes & Average number of comments from publications collected for $\mathrm{y}_{2} 2$ \\
\hline y_10 & Comments &
\end{tabular}

Table no. 3 - Variables related to "conversation" and "influence"

\begin{tabular}{cll}
\hline y2_1 & Hashtags & $\begin{array}{l}\text { Number of relevant hashtags related to official profiles (threshold at more } \\
\text { than 50 publications) }\end{array}$ \\
\hline y2_2 & Instagrammer & $\begin{array}{l}\text { Number of publications of the most influential instagrammer for a given } \\
\text { hashtag }\end{array}$ \\
\hline y2_3 & Popularity & $\begin{array}{l}\text { Number of publications related to all instagrammers that are using the most } \\
\text { relevant hashtag }\end{array}$ \\
\hline
\end{tabular}

\subsection{Econometric models}

The second step of this study aimed to detect which firms' characteristics explain the metrics collected on the Instagram profiles. In this regard, country, subsectors and size were considered as potential explanatory factors to explain different behavior of each firm and its corresponding communities. The following Ordinary Least Squares regression models are defined: 


$$
\begin{gathered}
\text { presence }: \mathrm{y}_{i j}=\alpha_{1 i}+\beta_{i k} \text { Country }_{k j}+\gamma_{i l} \text { Sector }_{l j}+\theta_{i} \log (\text { Sales })_{j}+\mu_{i j} \\
\text { impact: } \mathrm{y}_{m j}=\alpha_{2 \mathrm{~m}}+\beta_{\mathrm{mk}} \text { Country }_{k j}+\gamma_{m l} \text { Sector }_{l j}+\theta_{m} \log (\text { Sales })_{j}+\mu_{m j} \\
\text { conversation: } \mathrm{y}_{n j}=\alpha_{3 n}+\beta_{3 k} \text { Country }_{k j}+\gamma_{3 l} \text { Sector }{ }_{j}+\theta_{3} \log (\text { Sales })_{j}+\mu_{n j} \\
\text { influence }: \mathrm{y}_{2}{ }_{2 j} j=\alpha_{4}+\beta_{4 k} \text { Country }_{k j}+\gamma_{4 l} \text { Sectorl }_{j}+\theta_{4} \log (\text { Sales })_{j}+\mu_{2}{ }_{2} j
\end{gathered}
$$

where:

$i$ denotes the variables from y1 to y7 (see Table no. 2)

$j$ denotes the firms

$k$ denotes the countries

$l$ denotes the subsectors

$m$ denotes the variables from y8 to $y 10$ (see Table no. 2 )

$n$ denotes the variables from y2_1 to y2_3 (see Table no. 3 )

$\alpha$ denotes the intercept of the models

$\beta$ denotes the coefficient associated with the country of each company

$\gamma$ denotes the coefficient associated with the subsectors of each company

$\theta$ denotes the coefficient associated with the size of each company (proxied as logarithmic scale of revenues for the fiscal year 2017)

$\mu$ denotes the standard error of the models.

\section{RESULTS}

\subsection{Presence and impact}

Results in Table no. 4 suggest that 50 over 111 corporations present an official profile on Instagram. Once they decide to be present, companies do tend to use the available mechanism like videos or stories ( $84 \%$ and $68 \%$ of the companies, respectively). From these 50 firms (Table no. 5), a majority offers corresponding profiles at Facebook (92\%) and Twitter (96\%), along with links to the official corporate site $(100 \%)$. In summary, the first result of our analysis is that the use of Instagram by the selected firms is still scarce. However, corporations are using Instagram as an additional channel in their current digital communication.

Table no. 4 - "Presence" of firms at Instagram

\begin{tabular}{lccc}
\hline & y_2 Publications & Y_3 Videos & y_4 Stories \\
\hline Mean & 1198.880 & $84 \%$ & $68 \%$ \\
\hline Maximum & 6169.000 & & \\
\hline Minimum & 60.00000 & & \\
\hline Std. Dev. & 1183.764 & & \\
\hline Obs. & 50 & & \\
\hline
\end{tabular}

Table no. 5 - Coherence between social media platforms

\begin{tabular}{lcc}
\hline & y_5 Link to corporate website y_6 Link to Facebook account y_7 Link to Twitter account \\
\hline$\%$ & $100 \%$ & $92 \%$ \\
\hline Obs. & 50 & $96 \%$ \\
\hline
\end{tabular}


Figures no. 1 and no. 2 account for the relationships between presence and impact, that is, the number of publications from these official profiles and the feedback they receive from followers. According to this, these users are somehow reactive to the stream of pictures and texts disclosed by firms. This confirms the bidirectional role of social media platform in empowering individuals over corporations in the digital dialogue.
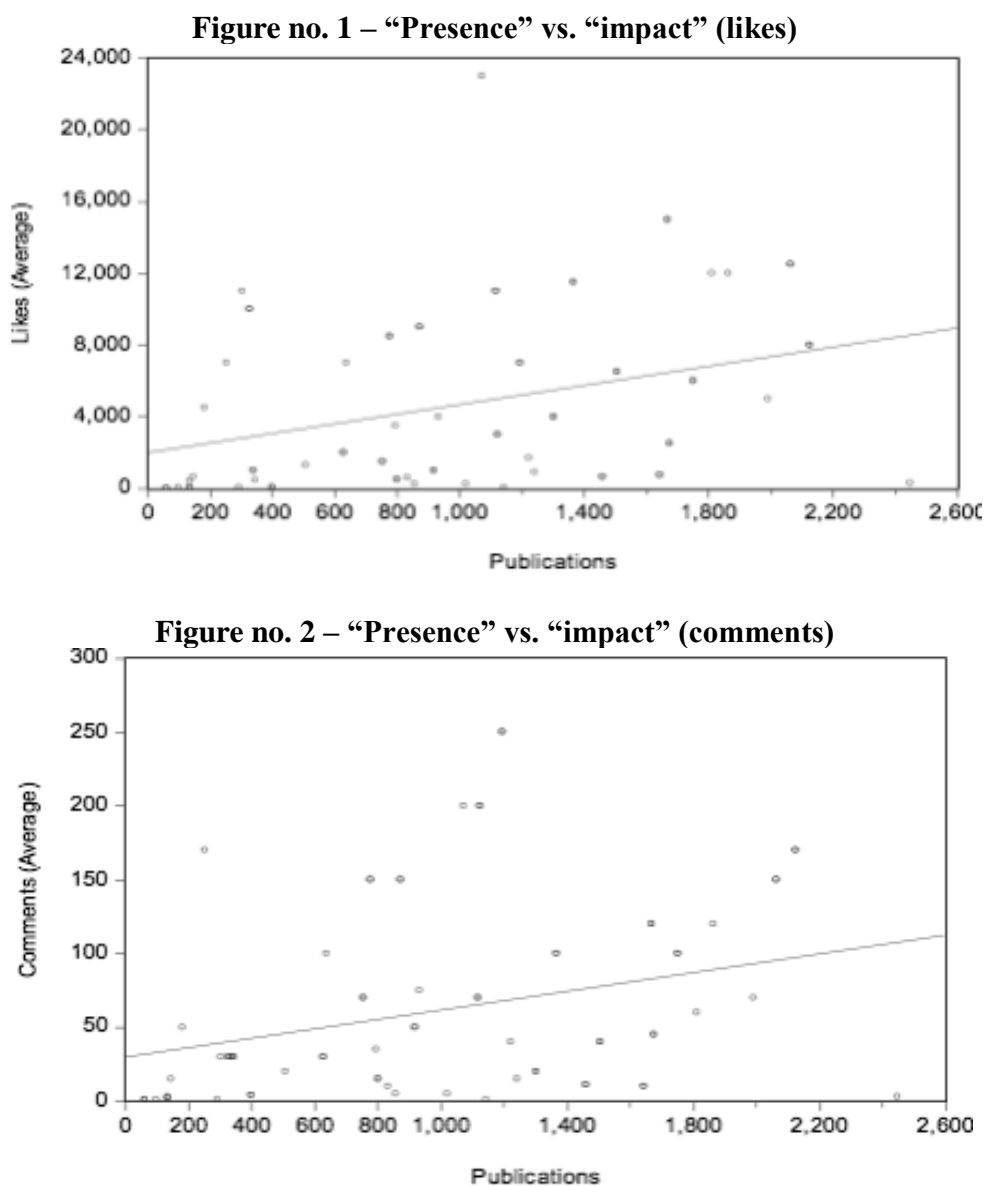

Based on the descriptive statistics, we ran the OLS regression models (1) and (2) to estimate the potential explanatory factors of the firms' presence and impact on Instagram. Table no. 6 shows the model's results of presence, being y1 Instagram profile the dependent variable. Two factors significantly explain such variable: US $\left(\beta_{i k}=0.3059\right.$, significant at $1 \%$ level) and $\log ($ Sales $)\left(\theta_{i}=-0.04293\right.$, significant at $5 \%$ level $)$. The $\mathrm{R}$ indicates that these two factors explain, ceteris paribus, $16.12 \%$ of the variation of presence (F-statistic significant at $1 \%$ level). We did not find any significant results for model (2) on impact. Therefore, the second finding of the study is that American corporations seem to be more prone to launch an Instagram profile, while large corporations are in general more reluctant to appear in it, according to the OLS estimation. 
Table no. 6 - OLS regression. Explanatory factors for "presence"

\begin{tabular}{|c|c|}
\hline \\
\hline \multicolumn{2}{|l|}{ Method: Least squares } \\
\hline Sample: 1111 & \\
\hline Variable & Coefficient \\
\hline $\mathrm{C}$ & $1.341897 * *$ \\
\hline US & $0.305900 * *$ \\
\hline $\log ($ Sales $)$ & $-0.042930 *$ \\
\hline R-squared & 0.161209 \\
\hline F-statistic & $10.37840 * *$ \\
\hline
\end{tabular}

\subsection{Conversation and influence}

When moving from official to unofficial communication, it is interesting to see that intermediation firms in tourism industry are the most likely to both maintain official profiles and to be able to generate external conversation by means of hashtags (Table no. 7). Additionally, Table no. 8 confirms how relevant is the conversation outside the official profiles, i.e., over three times on average with respect to the communication carried on at the official profile. No significant results were found for the estimation models (3) and (4) to explain the firms' conversation and influence on Instagram. Therefore, such evidence reveal that users are taking part in the digital conversation on their own, despite the influence of firms' characteristics on this behavior is not clear. However, results confirm the crucial role of the influencers ("instagrammer") in fostering the corporate dialogue of tourism firms in a digital context.

Table no. 7 - "Presence" vs. "conversation"

\begin{tabular}{lcc}
\hline & y_1 Instagram profile & y2_1 Hashtags \\
\hline Sector & Proportion & Mean \\
\hline Accommodation & $50 \%$ & 1.80 \\
\hline Intermediation & $60 \%$ & 2.66 \\
\hline Other & $46 \%$ & 2.08 \\
\hline Transport & $44 \%$ & 2.29 \\
\hline All & $46 \%$ & 2.16 \\
\hline
\end{tabular}

Table no. 8 - "Presence" vs. "influence"

\begin{tabular}{lccc}
\hline & $\begin{array}{c}\text { y_2 Number of } \\
\text { publications }\end{array}$ & $\begin{array}{c}\text { y2_3 } \\
\text { Popularity }\end{array}$ & $\begin{array}{c}\text { y2_3/y_2 } \\
\text { Proportion }\end{array}$ \\
\hline Sector & Mean & Mean & \\
\hline Accommodation & 979 & 2781 & 2.8 \\
\hline Intermediation & 1405 & 739 & 0.5 \\
\hline Other & 981 & 3096 & 3.1 \\
\hline Transport & 944 & 4151 & 4.3 \\
\hline All & 994 & 3388 & 3.4 \\
\hline
\end{tabular}




\section{IMPLICATIONS, LIMITATIONS, AND FUTURE RESEARCH}

The use of Instagram, compared to other social network sites like LinkedIn or even Facebook, is still in its infancy, even it is growing rapidly. For its special features, Instagram is not simply the next episode in corporate digital presence, but a new arena where users have a more substantial portion of power, audience and influence.

Even in this exploratory stage, it is possible to identify several implications for practice and research. Concerning practice, our findings suggest that the presence and impact of companies at Instagram are a highly important source for driving stakeholders' conversation within the digital arena. First, tourism companies are exploiting the powerful of this social network which allows the creation of a thread of photographs and videos with a specific theme, like a destination or a specific corporation. This helps travelers in their decisionmaking processes (Gretzel et al., 2015). Second, we recognize the magnitude of the opinion leaders in increasing the stakeholders' intention to interact in the Instagram account conversation and influence. Following Casalo et al. (2020, p. 7) reasoning, "followers are involved in the value-creation process - they can contribute with their knowledge if they interact with the account, and the number of followers may increase if they recommend the account to others, increasing the value of the opinion leader". This requires, in turn, that companies should take into account both the content published by opinion leaders and their own target audience. Such issue could be addressed by applying some emergent technologies, like the Internet of Things, which allow multiple addressability to gather stakeholders' preferences and behaviors (Valentinetti \& Flores Muñoz, 2021). Additionally, our research finding show that popularity - in terms of number of publications related to all instagrammers that are using the most relevant hashtag - is over three times on average with respect to the communication carried on by companies with an official profile. This means that new companies' profiles would easily leverage their digital visibility thanks to the influence of the conversation that arise outside the official profiles.

Research implications of this study contribute to the literature on corporate disclosure and information asymmetry. As argued by Lardo et al. (2017, p. 76), we contend "the potential for social media managers to use disclosed information, whether voluntarily or involuntarily, to lead and influence their company's decision-making processes". Overall, the key hint is that managers may use social media to mitigate the agency problem. It is interesting to evaluate if social media disclosure may succeed the traditional communication tools, like the annual reports, to address some information asymmetry problems. Furthermore, our first evidence based on the combination of presence, impact, conversation and influence open new perspectives under the signalling approach to investigate how organizations reacts to the environment in absence of all the available information (Spence, 1973).

Future research could be inspired by the limitations of this study. First, longitudinal studies are needed to extend our cross-sectional analysis. In this regard, two metrics proposed by Caputo et al. (2017, p. 27) could be used: instability, to measure "the fluctuation in companies' communications via social media in the analyzed period"; and previous activity, to measure "the evolution in the frequency of companies' communication via social media along time". Crosscomparison between different industrial sectors is also needed. Additionally, future research may apply existing theoretical frameworks including psychological, cognitive and social factors to investigate companies' communication via Instagram. For example, the Value compatibility framework could be applied to consider structural, practical and cultural dimensions as in Flores 
Muñoz, Valentinetti, Mora Rodríguez, and Mena Nieto (2018). Also, the stakeholder theory offers appropriate lens to investigate the stakeholders' information needs and awareness towards the value creation process. Incremental empirical research in this matter will be required as the conversation outside official profiles is bigger, and potentially, more significant than the traditional conversation controlled by the firms. Finally, content and sentiment analysis, as well as text mining, should be applied to properly evaluate both the quality of companies' disclosure and the users' comments.

\section{ORCID}

Josué Gutiérrez-Barroso (iD http://orcid.org/0000-0001-5968-3254

Alberto Javier Báez-García (iD http://orcid.org/0000-0002-6278-8169

Francisco Flores-Muñoz (iD http://orcid.org/0000-0002-8194-9394

Diego Valentinetti iD http://orcid.org/0000-0003-3961-9225

\section{References}

Amornpashara, N., Rompho, N., \& Phadoongsitthi, M. (2015). A study of the relationship between using Instagram and purchase intention. Journal for Global Business Advancement, 8(3), 354-370. http://dx.doi.org/10.1504/JGBA.2015.071330

Blazevic, V., Wiertz, C., Cotte, J., de Ruyter, K., \& Keeling, D. I. (2014). GOSIP in cyberspace: Conceptualization and scale development for general online social interaction propensity. Journal of Interactive Marketing, 28(2), 87-100. http://dx.doi.org/10.1016/j.intmar.2013.09.003

Bonson Ponte, E., Torres, L., Royo, S., \& Flores Muñoz, F. (2012). Local e-government 2.0: Social media and corporate transparency in municipalities. Government Information Quarterly, 29(2), 123-132. http://dx.doi.org/10.1016/j.giq.2011.10.001

Boylan, D. H., \& Boylan, C. L. (2017). Technology in Accounting: Social Media as Effective Platform for Financial Disclosures. The International Journal of Digital Accounting Research, 17, 93-109. http://dx.doi.org/10.4192/1577-8517-v17_4

Caputo, F., Buhnova, B., Evangelista, F., \& Russo, G. (2017). A Systems View of Companies' Communication in Online Social Environments. Journal of Organisational Transformation \& Social Change, 14(1), 21-38. http://dx.doi.org/10.1080/14779633.2017.1291144

Casalo, L. V., Flavian, C., \& Ibanez-Sanchez, S. (2020). Influencers on Instagram: Antecedents and consequences of opinion leadership. Journal of Business Research, 117, 510-519. http://dx.doi.org/10.1016/j.jbusres.2018.07.005

Clair, A., \& Mandler, J. (2019). Building relationships with the new media in a cyber landscape. The Journal of Business Strategy, 40(6), 49-54. http://dx.doi.org/10.1108/JBS-08-2019-0154

Debreceny, R. S., Wang, T., \& Zhou, M. J. (2019). Research in Social Media: Data Sources and Methodologies. Journal of Information Systems, 33(1), 1-28. http://dx.doi.org/10.2308/isys-51984

Farkas, M., \& Keshk, W. (2019). How Facebook influences non-professional investors' affective reactions and judgments: The effect of disclosure platform and news valance. Journal of Financial Reporting and Accounting, 17(1), 80-103. http://dx.doi.org/10.1108/JFRA-10-2017-0092

Fatanti, M. N., \& Suyadnya, I. W. (2015). Beyond User Gaze: How Instagram Creates Tourism Destination Brand? Procedia: Social and Behavioral Sciences, 211, 1089-1095. http://dx.doi.org/10.1016/j.sbspro.2015.11.145

Flores Muñoz, F., Valentinetti, D., Mora Rodríguez, M., \& Mena Nieto, A. (2018). The Role of XBRL on EMAS Reporting: An Analysis of Organisational Value Compatibility. Scientific Annals of Economics and Business, 65(4), 497-514. http://dx.doi.org/10.2478/saeb-2018-0025 
Freberg, K., Graham, K., McGaughey, K., \& Freberg, L. A. (2011). Who are the social media influencers? A study of public perceptions of personality. Public Relations Review, 37(1), 90-92. http://dx.doi.org/10.1016/j.pubrev.2010.11.001

Geurin-Eagleman, A. N., \& Burch, L. M. (2016). Communicating via photographs: A gendered analysis of Olympic athletes' visual self-presentation on Instagram. Sport Management Review, 19(2), 133145. http://dx.doi.org/10.1016/j.smr.2015.03.002

Grancay, M. (2014). Airline Facebook pages-a content analysis. European Transport Research Review, 6(3), 213-223. http://dx.doi.org/10.1007/s12544-013-0126-9

Gretzel, U., Sigala, M., Xiang, Z., \& Koo, C. (2015). Smart tourism: Foundations and developments. Electronic Markets, 25(3), 179-188. http://dx.doi.org/10.1007/s12525-015-0196-8

Harrigan, P., Evers, U., Miles, M., \& Daly, T. (2017). Customer engagement with tourism social media brands. Tourism Management, 59, 597-609. http://dx.doi.org/10.1016/j.tourman.2016.09.015

Healy, P. M., \& Palepu, K. G. (2001). Information asymmetry, corporate disclosure, and the capital markets: A review of the empirical disclosure literature. Journal of Accounting and Economics, 31(1), 405-440. http://dx.doi.org/10.1016/S0165-4101(01)00018-0

Hosseini, M., \& Ghalamkari, A. (2018). Analysis Social Media Based Brand Communities and Consumer Behavior: A Netnographic Approach. International Journal of E-Business Research, 14(1), 37-53. http://dx.doi.org/10.4018/IJEBR.2018010103

Howard, D., Mangold, W. G., \& Johnston, T. (2014). Managing your social campaign strategy using Facebook, Twitter, Instagram, YouTube \& Pinterest: An interview with Dana Howard, social media marketing manager. Business Horizons, 5(57), 657-665. http://dx.doi.org/10.1016/j.bushor.2014.05.001

Kipp, P. C., Zhang, Y., \& Tadesse, A. F. (2019). Can Social Media Interaction and Message Features Influence Nonprofessional Investors' Perceptions of Firms? Journal of Information Systems, 33(2), 77-98. http://dx.doi.org/10.2308/isys-52067

Lardo, A., Dumay, J., Trequattrini, R., \& Russo, G. (2017). Social media networks as drivers for intellectual capital disclosure: Evidence from professional football clubs. Journal of Intellectual Capital, 18(1), 63-80. http://dx.doi.org/10.1108/JIC-09-2016-0093

Lee, E., Lee, J. A., Moon, J. H., \& Sung, Y. (2015). Pictures speak louder than words: Motivations for using Instagram. Cyberpsychology, Behavior, and Social Networking, 18(9), 552-556. http://dx.doi.org/10.1089/cyber.2015.0157

Lee, L. F., Hutton, A. P., \& Shu, S. (2015). The Role of Social Media in the Capital Market: Evidence from Consumer Product Recalls. Journal of Accounting Research, 53, 367-404. http://dx.doi.org/10.1111/1475-679X.12074

Liu, R., \& Suh, A. (2017). Self-Branding on Social Media: An Analysis of Style Bloggers on Instagram. Procedia Computer Science, 124, 12-20. http://dx.doi.org/10.1016/j.procs.2017.12.124

MacDowall, L. J., \& de Souza, P. (2018). 'I'd Double Tap That!!': Street art, graffiti, and Instagram research. Media Culture \& Society, 40(1), 3-22. http://dx.doi.org/10.1177/0163443717703793

Marine-Roig, E., Martin-Fuentes, E., \& Daries-Ramon, N. (2017). User-Generated Social Media Events in Tourism. Sustainability (Basel), 9(12), 2250. http://dx.doi.org/10.3390/su9122250

Mora Rodríguez, M., Flores Muñoz, F., \& Valentinetti, D. (2021). Corporate impact of carbon disclosures: A nonlinear empirical approach. Journal of Financial Reporting and Accounting, 19(1), 4-27. http://dx.doi.org/10.1108/JFRA-01-2020-0002

Ramirez, Y., \& Tejada, A. (2019). Digital transparency and public accountability in Spanish universities in online media. Journal of Intellectual Capital, 20(5), 701-732. http://dx.doi.org/10.1108/JIC-022019-0039

Romao, M. T., Moro, S., Rita, P., \& Ramos, P. (2019). Leveraging a luxury fashion brand through social media. European Research on Management and Business Economics, 25(1), 15-22. http://dx.doi.org/10.1016/j.iedeen.2018.10.002 
Rosli, N. A., \& Husin, M. H. (2019). Initial Exploration on an Effective Social Media Analytics Method and Algorithm for Instagram Hashtags. International Journal of E-Business Research, 15(3), 115. http://dx.doi.org/10.4018/IJEBR.2019070101

Schlosser, A. E. (2005). Posting versus lurking: Communicating in a multiple audience Context. The Journal of Consumer Research, 32(2), 260-265. http://dx.doi.org/10.1086/432235

Schmidbauer, H., Rosch, A., \& Stieler, F. (2018). The 2016 US presidential election and media on Instagram: Who was in the lead? Computers in Human Behavior, 81, 148-160. http://dx.doi.org/10.1016/j.chb.2017.11.021

Sembada, A. Y., \& Koay, K. Y. (2019). How perceived behavioral control affects trust to purchase in social media stores. Journal of Business Research, 130, 574-582. http://dx.doi.org/10.1016/j.jbusres.2019.09.028

Spence, M. (1973). Job Marketing Signalling. The Quarterly Journal of Economics, 87(3), 355-374. http://dx.doi.org/10.2307/1882010

STOXX. (2018). Retrieved from https://www.stoxx.com/index-details?symbol=SXG57P

Thelander, A., \& Cassinger, C. (2017). Brand new images? Implications of Instagram photography for place branding. Media and Communication, 5(4), 6-14. http://dx.doi.org/10.17645/mac.v5i4.1053

Valentinetti, D., \& Flores Muñoz, F. (2021). Internet of Things: Emerging impacts on digital reporting. Journal of Business Research, 131, 549-562. http://dx.doi.org/10.1016/j.jbusres.2021.01.056

Waheed, A., Farrukh, M., Zameer, H., \& Khan, S. Z. (2019). Understanding the Impact of Social Apps and Social Network Sites on Consumer's Online Purchase Intention. Global Business Review, 22(3), 1-16. http://dx.doi.org/10.1177/0972150918816901

Zhu, Y. Q., \& Chen, H. G. (2015). Social media and human need satisfaction: Implications for social $\begin{array}{llll}\text { media } \quad \text { marketing. } & \text { 335iness }\end{array}$ http://dx.doi.org/10.1016/j.bushor.2015.01.006

\section{Copyright}

This article is an open access article distributed under the terms and conditions of the Creative Commons Attribution-NonCommercial-NoDerivatives 4.0 International License. 


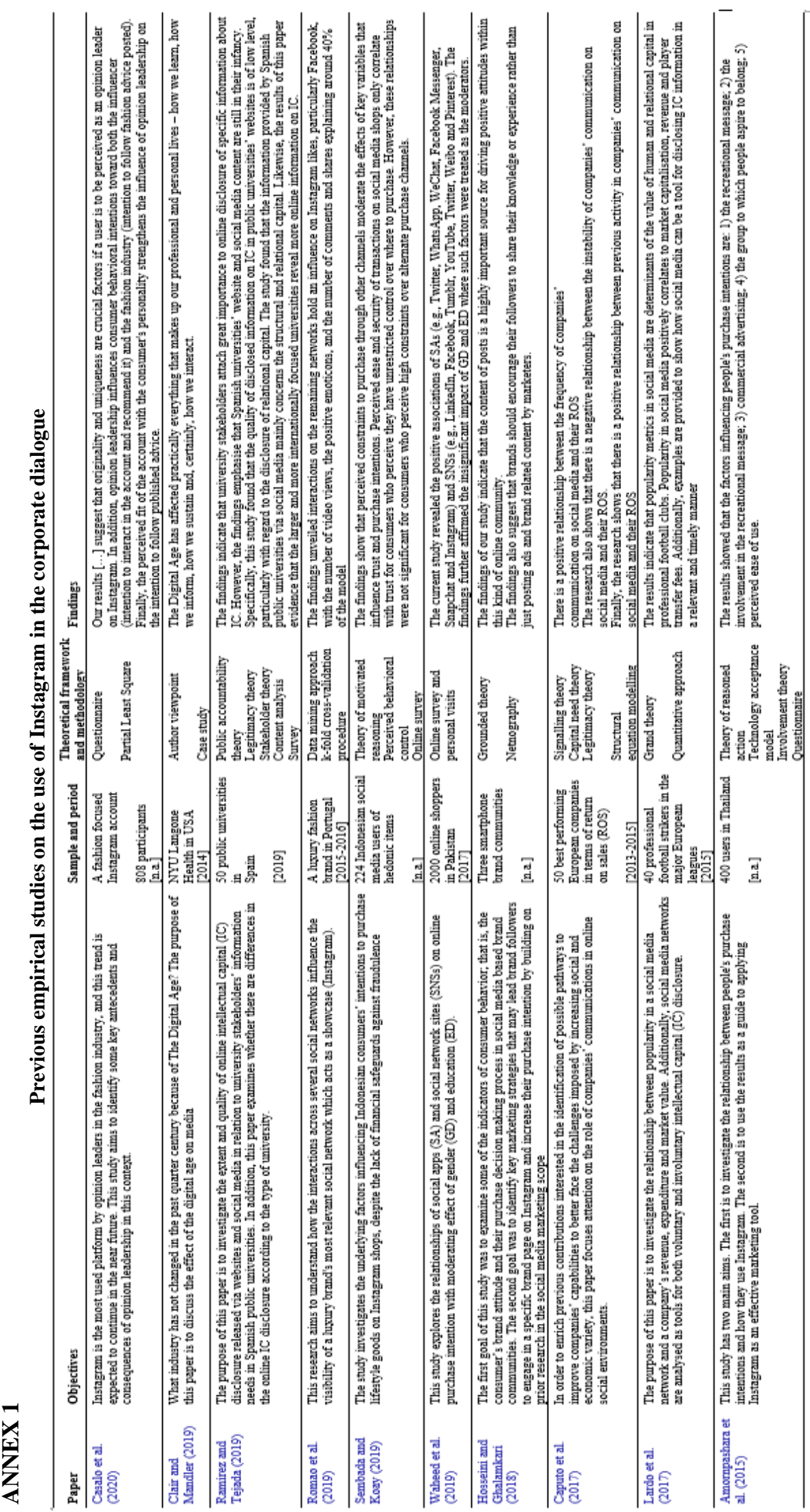

